\title{
The Impact of Air Quality on Effective Labor Supply: Based on the Survey Data of Zhejiang Province in China
}

\author{
Yongliang Yang ${ }^{1,2, * \mathbb{D}}$, Jing Fang ${ }^{1}$, Wen Wang ${ }^{1}$, Yan $\mathrm{Li}^{1}$ and $\mathrm{Yi} \mathrm{Li}^{3,4,5}$ \\ 1 School of Economics and Management, Zhejiang Sci-Tech University, Hangzhou 310018, China; \\ 2018333503071@mails.zstu.edu.cn (J.F.); 2018333503213@mails.zstu.edu.cn (W.W.); \\ 2019333503143@mails.zstu.edu.cn (Y.L.) \\ 2 Ecological Civilization Research Center of Zhejiang Province, Hangzhou 310018, China \\ 3 Faculty of Tourism and Culture, International United Faculty between Ningbo University and University of \\ Angers, Ningbo University, Ningbo 315201, China; liyi1@nbu.edu.cn \\ 4 East China Sea Institute, Ningbo University, Ningbo 315211, China \\ 5 Center for Ecological Civilization of Yangtze River Delta, Ningbo University, Ningbo 315211, China \\ * Correspondence: royyang@zju.edu.cn
}

check for updates

Citation: Yang, Y.; Fang, J.; Wang, W. Li, Y.; Li, Y. The Impact of Air Quality on Effective Labor Supply: Based on the Survey Data of Zhejiang Province in China. Sustainability 2021, 13, 4012. https://doi.org/10.3390/su13074012

Received: 8 March 2021

Accepted: 31 March 2021

Published: 3 April 2021

Publisher's Note: MDPI stays neutral with regard to jurisdictional claims in published maps and institutional affiliations.

Copyright: (c) 2021 by the authors. Licensee MDPI, Basel, Switzerland. This article is an open access article distributed under the terms and conditions of the Creative Commons Attribution (CC BY) license (https:// creativecommons.org/licenses/by/ $4.0 /)$.

\begin{abstract}
Labor is one of the most important factors of production and the basis for the development of social productivity. China's aging population problem is serious, and the study of the labor supply is of great importance in order to achieve its second centenary goal regarding social development. In this study, four stage mixed sampling was used to conduct a questionnaire survey in the Zhejiang province of China, and 590 valid questionnaires were obtained. An ordered logit model and sample selection model were used to analyze the impact of air quality on the effective labor supply. The results show that the effective labor supply was significantly correlated with air quality. That is, the worse the air quality was, the lower the effective labor supply was, although this relationship was more explicit for people who worked indoors. When air quality impedes residents' daily lives and even affects their health, it indirectly affects the effective supply of local labor. This paper indicates the causal relationship between economic development and the ecological environment and has enlightening significance for the realization of sustainable development.
\end{abstract}

Keywords: air quality; effective supply of labor; ordered logit model

\section{Introduction}

Air quality is strongly related to residents' lives and health. However, the urban population and energy consumption continue to grow along with economic development, causing a series of environmental problems [1]. As a byproduct of economic development, air pollution has always existed throughout the process of human development, posing a serious threat to people's lives. The year 2020 was the final year of the "13th Five-Year Plan" of China.

The labor force is an indispensable basic component of social productivity. Human capital is an important factor in the development process, and air quality problems can reduce the supply of labor through many mechanisms, such as human health conditions [2]. In the process of social and economic transformations and upgrading, the acceleration of industrialization and urbanization has generated a series of environmental problems in cities. There is a tight link between environmental regulation and employment levels [3]. As labor supply is concentrated in cities, the study of the impact of urban air quality on the effective labor supply is an inevitable requirement for the transformation and upgrade of the manufacturing industry. A country pursues high-quality development in the process of transforming and upgrading the manufacturing sector, so it needs to have a sufficient labor force. Since environmental quality is closely related to the labor participation rate, people inevitably demand physical and mental health and a high-quality living environment. 
At present, there are many literatures on the influence of air pollution on residents' choice of work behavior from different aspects. From the perspective of environment and public health, air pollution will damage the physical and mental health of residents, which definitely weakens the supply of labor $[4,5]$. Research also confirms that workers participation rate will decrease when air pollution occurs [6-8]. Increasing defensive spending, such as installing air purification equipment, can reduce the negative impact of air pollution, but it increases the cost. Workers either work harder to earn money or simply leave the polluted areas [9-12]. In order to avoid demand, people will flow from high pollution areas to places with good air quality under the similar conditions [13-15]. The subjective well-being of residents will also be affected by air quality, which may affect the willingness and attitude of residents to work [16-19]. Therefore, air quality may affect the quantity and quality of the labor supply, and there is no consistent conclusion at present.

The Yangtze River Delta is the most active region in China's economy, and Zhejiang Province is the most typical region for China to integrate into the world economy. Thanks to the processing-oriented export-oriented economy, Zhejiang Province is one of the provinces with the highest per capita disposable income, which also brings a heavy environmental burden to Zhejiang Province. With the improvement of cognitive level and the awakening of public awareness, Zhejiang Province has been reflecting on the past development model and continuously promoting the outward transfer and upgrade of heavy pollution industries. Zhejiang Province has shown an obvious structural shortage of labor force in recent years, which is also the epitome of the gradual disappearance of a labor dividend in China. The study of air quality in Zhejiang Province on the supply of labor has very important practical significance for the choice of environmental governance and economic development models in developing countries. From the micro empirical research level, empirical research on the impact of air quality on labor supply in Zhejiang Province is relatively lacking.

This paper focuses on the impact of air quality on the effective supply of labor. We used field survey data from five prefecture-level cities in Zhejiang Province to analyze the possible influence of air quality on the labor supply by using an ordered logit regression and a sample selection model. Studies have shown that air quality has a significant impact on labor supply and this relationship is clearer among individuals who work indoors. We tested robustness with a stepwise regression. Additionally, group regressions were conducted according to the characteristics of age and region to test for heterogeneity.

This article makes two main contributions. First, there are few studies on the impact of air quality on the labor supply in Zhejiang Province. Our study fills this gap in the relevant research fields and reveals the close causal relationship between economic development and the ecological environment through investigation and research at a local level, increasing the public's attention to the protection of the ecological environment. Second, the index we used to measure the labor supply was a weighted average of the five indexes of residents expected lifestyle, purchase of medical insurance, life satisfaction, health level, and labor participation rate over the next three years, which allowed us to measure the impact of air quality on residents from multiple dimensions.

This paper is divided into five parts. The second part summarizes the results of previous research. The third part introduces the design of the questionnaire and the sampling design process. The fourth part presents the results of the empirical analysis. The fifth part includes the conclusion and policy suggestions.

\section{Literature Review}

2.1. Air Quality Reduces the Quantity and Quality of Labor Supply

2.1.1. Human Health

Urban air pollution causes approximately 800,000 deaths, and 4.6 million disabilityadjusted lives are lost each year according to estimates by the World Health Organization. At present, relevant studies have pointed out that air quality affects human health, labor supply, and employment [1-3]. Air pollution has become a global health problem. How- 
ever, there are many obstacles to eliminating air pollution because of the large number of air pollutants, insufficient funding for monitoring and reduction programs, and the political and social challenges in determining policies to limit emissions [4]. Air pollution has become a growing concern in society and poses a great threat to human health and the environment [20]. Air quality is closely related to all aspects of human life and has the most direct impact on human health. In addition, air quality affects respiratory diseases (pneumonia, asthma, etc.), the proportion of deaths and hospitalizations due to respiratory diseases, which is related to differences in age, gender, and exposure to pollution. Decreased air quality increases the prevalence of respiratory diseases, mortality from malignant lung cancers, and the incidence of neurological, cardiac, and neurovascular diseases [21]. The characteristics of the premature deaths caused by PM2.5 (Fine Particulate Matters) in the different types of cities in China provide evidence [5,22,23]. Luo et al. (2018) concluded that the mortality rate in areas with better air quality was much lower than that in areas with high levels of pollution. This affects social stability and hinders the sustainable development of the economy [24]. Health inequality is widespread in China and is more serious in rural areas. The damage to health caused by pollution has further exacerbated the differences in income levels due to different degrees of health inequality across the population, while pollution has simultaneously increased the impact of income inequality on health inequality [25]. The improvement of air quality reduces risks to human health and increases the infant birth rate, thereby causing an increase in the effective supply of labor.

An increasing number of studies have proven that air quality not only affects human physiological health but also affects human psychological health. Studies have shown that air pollution can increase the incidence of mental illnesses such as depression and schizophrenia and that improving air quality can effectively reduce the occurrence of these mental illnesses $[5,26,27]$. Individuals' subjective evaluations of air quality affect their mental health by affecting their daily activities and living conditions. A decrease in air quality may affect people's social interactions, leading to negative emotions and affecting people's subjective mood and happiness [28]. Dzhambul et al. (2018) concluded that air pollution is substantially related to mental health in different ways, as an increase in the level of air pollution strengthens residents' perception of health and reduces the public's acceptance rate for risk [29]. However, some scholars have pointed out that while air quality problems can have a negative impact on mental health, research in this area is preliminary. These scholars believe that the effect of air quality on human mental health is indirect [30]. Moreover, some scholars have pointed out that when assessing the impact of air pollution on mental health, the unilateral impact of air pollution may be overestimated while the impact of the overall environment, including factors such as noise pollution, on psychological health may be underestimated [31]. Air pollution has a negative impact on human health through direct or indirect mechanisms. If air pollution exists for a long time, it worsens human health, which is not conducive to the supply of labor.

\subsubsection{The Labor Participation Rate}

The influence of air quality on the labor force participation rate can be divided into two main effects: the hours supplied and the number of workers. Air quality has a great impact on economic development, mainly through reductions in the labor supply, the destruction of human capital, and counter-urbanization [6]. When people are faced with poor air quality, their choice to work is affected, which affects the labor participation rate. The substitution effect of air quality reduction is greater than the income effect, and the labor supply is reduced through both direct and indirect effects. The labor force includes not only people who work in conventional jobs but also professional athletes and other similar types of workers. Air quality problems also have a significant negative impact on the efficiency and participation rate of athletes. Poor air quality causes the physical state of the labor force to deteriorate in a variety of ways, leading to a lower participation rate and a reduction in efficiency [7]. A decline in air quality decreases the health level of workers 
and increases the time taken for sick leave, thus reducing the hours supplied and affecting the labor participation rate. From the perspective of families, the immunity of elderly family members and of children is weaker than that of adults. Vulnerable members are more likely to get sick from poor air quality. Workers need to spend more time taking care of their families, thus reducing their hours supplied and the labor participation rate. Before the national implementation of clean air, air pollution significantly reduced the output of the manufacturing industry, which is an important reason for the reduction in the labor participation rate [8].

\subsubsection{Individual Mobility}

The air quality problem has a significant negative impact on the mobility of residents. The more serious the air pollution is, the greater the willingness of residents to move. People always have a greater preference for areas with better air quality and superior environmental quality. Specifically, the negative impact of air pollution on elderly individuals and the level of education within the urban floating population and the rural floating population is low. Air pollution damages human capital investments and may become a barrier to the sustainable development of cities [9,10]. Additionally, rising levels of air pollution have seriously hampered technological innovation. Wang and $\mathrm{Wu}$ (2021) found that air pollution has a significant crowding-out effect on innovation funding, thus reducing innovation output, but it has not yet produced a significant brain drain [11]. Policy makers should formulate targeted environmental regulatory policies and effective measures to improve air quality. The labor force is more likely to migrate to cities with better air quality, which further affects the labor supply in different regions and the innovative behavior of individuals. People tend to have a greater preference for areas with higher air quality. Without considering other factors, high-quality talent tends to choose to leave areas with poor air quality and to move to areas with better air quality, which results in a shortage of talent in certain regions and thus reduces the supply of labor [12].

\subsection{Air Pollution Increases Residents' Defensive Spending}

Air quality problems affect people's lives and health, and residents undertake certain measures to protect themselves. Studies have shown that air pollution has a significant impact on residents' medical insurance expenditures and health expenditures. An increase in air pollution has a positive impact on human health insurance expenditures, and air pollution affects medical and health expenditures by affecting residents' health mechanisms [32]. In addition, medical insurance has a significant impact on labor supply and plays an important role in the long-term sustainable supply of labor [13]. Chen and Chen (2021) pointed out that the residents' protective behaviors illustrate the existence of inequality in society [14]. Often when the air quality is poorer, it is assumed that with a higher economic capacity poor individuals could afford the fees and high costs of protective behavior, such as buying air purifiers. This means the exposure of poor individuals to air pollution is greater than the exposure to air pollution among rich individuals. This reflects the trend toward inequality in quality of life in China, which has important implications for the formulation of environmental protection policies. From the perspective of avoidance behavior, the aggravation of air pollution may increase the purchase of medical insurance, and women, children, and those in high-income groups are more willing to purchase medical insurance and have a stronger desire for self-protection [15].

A decrease in air quality can cause great economic losses. Estimations of people's willingness to pay to improve air quality may indirectly reflect the economic value of air quality and thus can also allow the economic losses caused by air pollution to be evaluated. Spending a certain amount of money for air pollution control-that is, relying on residents' willingness to pay-is an important policy for pollution control. However, some studies have shown that the public's willingness to pay to improve the environment is not very high. Additionally, in the actual social environment, the public is not willing to pay much money to improve air quality. They are more willing to spend money on personal protective 
measures such as air purifiers [33]. Air quality has a significant impact on the willingness to pay for environmental governance. The deterioration of air quality makes residents willing to improve current air quality [34]. Air pollution has a significant impact on residents willingness to pay environmental protection taxes. The more serious the pollution is, the more willing the residents are to pay environmental protection taxes [35]. Improvements in air quality are conducive to increasing the economic value of air [34]. In addition, a survey of China's public environmental awareness and household e-waste performance shows that residents are very willing to accept environmental responsibility; that is, they have a high willingness to pay [36].

\subsection{Air Quality Weakens People's Happiness}

With the exposure to air pollution and the improvement of residents' cognitive levels, air quality has a great impact on residents' life satisfaction. Chinese living in areas with poor air quality tend to be dissatisfied with law enforcement [16]. Tsurumi (2020) argued that air pollution affects residents' satisfaction and subjective well-being and noted that in China, life satisfaction is significantly reduced due to its health-related effects [17]. Therefore, when setting environmental standards to improve life satisfaction, it is important to consider not only health issues but also people's sense of crisis. Indoor air quality has also attracted increasing attention. Studies have shown that indoor air quality in the workplace (IAQ) is closely related to human health, comfort, and satisfaction, and poor air quality greatly reduces residents' life satisfaction [18,19]. Existing research [37] has estimated that human activities have caused the loss of air quality. The relationship between air pollution and life satisfaction provides further evidence that life satisfaction is negatively correlated with air pollution. When the level of air pollution is higher, the life satisfaction of residents is lower. Ahumada and Iturra (2021) also found that different concentrations of air pollutants are negatively correlated with public satisfaction. The higher the concentration of air pollutants, the lower the public satisfaction with the living environment [38]. At present, the aging of China's population is serious, and improving air quality is an urgent matter. Air pollution is a serious environmental problem in both developed and developing countries. In addition to having harmful effects on people's health, it also has negative effects on people's satisfaction and happiness [39]. Air quality plays an important role in people's lives, and people's lives are more or less affected by it. In addition, air pollution exacerbates social health inequality and reduces public life satisfaction. This is because high-income groups can afford to improve air quality, while low-income groups find it difficult to improve their situation. It is not difficult to see that places with poor air quality have lower levels of public satisfaction and happiness, and this has negative effects on human memory [38]. Studies have shown that differences in the spatial environment lead to differences in people's life satisfaction, which indicates the importance of improving air quality for the public [40]. Other studies have explored the relationships between air quality and green plant coverage, residents' satisfaction, and subjective well-being. It was found that the better the air quality and the higher the green plant coverage are, the more residents' satisfaction and subjective well-being also increase [41]. Air quality affects satisfaction and well-being largely through the same mechanisms that affect residents' health. When the air quality is poor, it will affect or even limits residents' travel and other activities, which undoubtedly reduces residents' satisfaction. Therefore, improving air quality greatly improves residents' satisfaction $[42,43]$.

\section{Questionnaire and Data}

\subsection{Questionnaire Design}

This study explored the impact of air quality on the effective labor supply and investigated the attitudes and opinions of the labor force in Zhejiang Province toward air pollution. China has been engaged in a tough battle against air pollution since the smog issue was exposed by the media in 2013 . The migration and settlement decisions of residents are very 
important for individuals and families, especially considering the rapid urbanization in China over the last several years.

To directly reflect feelings toward air pollution and the impact of air quality on the effective labor supply, stratified sampling and simple random sampling were conducted by age and region. Hangzhou, Ningbo, Jinhua, Jiaxing, and Huzhou were selected as the research sites. Additionally, the five representative cities selected are located in the east, west, north, south, and center of Zhejiang Province and basically cover Zhejiang Province. To achieve the desired results through the questionnaire, we strictly abided by the four basic principles of questionnaire design when designing the questionnaire: the functionality principle, the generalizability principle, the efficiency principle, and the maintainability principle. Therefore, with the goal of developing and enriching the existing theories, we conducted research from the perspectives of residents' health, the labor participation rate, medical insurance, individual mobility, and willingness to pay.

A survey was conducted through a combination of online and offline techniques. The preliminary survey period was from January to May 2020, during which time the survey was mainly distributed in the form of online questionnaires. From July to September 2020, to ensure safety, field investigations were carried out mainly through surface and ground investigations. Although face-to-face surveys are more expensive to implement than other types of surveys, they provide respondents with the opportunity to participate in the survey immediately and directly so as to provide effective responses. We conducted face-toface surveys of residents on the streets of our selected cities to determine the impact of air quality on the effective supply of labor. The questionnaire was conducted individually, one person per household. The questionnaire took 10-15 min to complete. Respondents were randomly selected on the basis of stratified sampling to obtain a more representative survey sample. The questionnaire was composed of five parts. The specific contents (Appendix A: Table A1) were as follows. The first part investigated the respondents' satisfaction with local air quality, and the second part investigated the respondents' awareness of air quality issues. The third part investigated the labor force participation rate of the respondents. The fourth part investigated the respondents' expenditure on protective behaviors. The fifth part investigated the respondents' socioeconomic background, including age, occupation, family income, marital status, education level, etc. The central question was: "Have you taken any days off work in the past year due to air pollution?"

\subsection{Sampling}

The questionnaire was conducted on the residential streets of five prefecture-level cities in Zhejiang Province. The survey team was composed of six people. Comprehensive training was conducted prior to conducting the survey to reduce the uncertainty in the survey results to an extent. For our complex sampling structure, we integrated a variety of random sampling methods to conduct four-stage mixed sampling. In the first stage, stratified random sampling was used to stratify the municipalities under the jurisdiction of Zhejiang Province according to five different geographical locations (east, south, west, north, and center). In the second stage, we selected 11 districts and counties in Hangzhou, Ningbo, Jinhua, Jiaxing, and Huzhou in Zhejiang Province by PPS sampling (Probability proportional scale sampling). The third stage used simple random sampling to sample subdistrict/town/township offices, and the fourth and final stage used stratified and proportional sampling based on age.

In this survey, a total of 839 respondents on 33 streets participated in the survey. Since it was difficult to confirm the residence of interviewees in advance by online questionnaire distribution in the early stage, 590 valid questionnaires were collected and sorted out after excluding those not in the survey area. We collected 271 valid questionnaires in Hangzhou City, 100 in Huzhou City, 92 in Ningbo City, 72 in Jinhua City, and 55 in Jiaxing City, respectively, with an effective rate of $70.32 \%$. To address any errors detected in data analysis, the returned questionnaires were numbered and classified to facilitate the retrieval of the original questionnaires for verification and correction. 


\subsection{Distribution of Respondents}

As shown in Table 1, among all respondents, people aged 21-30 accounted for $40.21 \%$ of the respondents to this survey, while those aged 16-20 and 31-40 accounted for 19.93\% and $22.88 \%$, respectively. The survey results show that a majority of respondents were mainly concentrated in the $16-40$ age range. A total of $90.99 \%$ of the respondents worked indoors, while the rest worked outdoors. More than half $(61.59 \%)$ of the respondents had a college education. Nearly two-thirds $(65.33 \%)$ of the respondents had a household income between 100,000 yuan and 500,000 yuan. Most families had fewer than six members, and a small number of families had more than seven members. In addition, nearly three-quarters of respondents' homes had no emissions near them.

Table 1. Characteristics of interviewees.

\begin{tabular}{|c|c|c|c|c|}
\hline Symbol & Variable & Description & Frequency & Proportion \\
\hline \multirow{5}{*}{ age } & \multirow{5}{*}{ Age } & 16-20 years old & 115 & $19.93 \%$ \\
\hline & & 21-30 years old & 232 & $40.21 \%$ \\
\hline & & $31-40$ years old & 132 & $22.88 \%$ \\
\hline & & $41-50$ years old & 54 & $9.36 \%$ \\
\hline & & $51-60$ years old & 44 & $7.63 \%$ \\
\hline \multirow{2}{*}{ wp } & \multirow{2}{*}{ Working place } & Indoor & 515 & $90.99 \%$ \\
\hline & & Outdoor & 51 & $9.01 \%$ \\
\hline \multirow{5}{*}{ edu } & \multirow{5}{*}{ Education } & Primary school & 15 & $2.60 \%$ \\
\hline & & Junior high school & 56 & $9.69 \%$ \\
\hline & & High school & 85 & $14.71 \%$ \\
\hline & & Bachelor's degree & 356 & $61.59 \%$ \\
\hline & & $\begin{array}{l}\text { Master's degree or } \\
\text { above }\end{array}$ & 66 & $11.42 \%$ \\
\hline \multirow{6}{*}{ income } & \multirow{6}{*}{$\begin{array}{l}\text { Family income } \\
\quad \text { (yuan) }\end{array}$} & Less than 50,000 & 31 & $5.43 \%$ \\
\hline & & $50,000-100,000$ & 125 & $21.89 \%$ \\
\hline & & $100,000-200,000$ & 208 & $36.43 \%$ \\
\hline & & $200,000-500,000$ & 165 & $28.90 \%$ \\
\hline & & $500,000-1.5$ million & 30 & $5.25 \%$ \\
\hline & & More than 1.5 million & 12 & $2.10 \%$ \\
\hline \multirow{3}{*}{ pop } & \multirow{3}{*}{ Household size } & $3-1$ & 263 & $46.63 \%$ \\
\hline & & $6-4$ & 294 & $52.13 \%$ \\
\hline & & 7 or more & 7 & $1.24 \%$ \\
\hline \multirow{2}{*}{ fluegas } & \multirow{2}{*}{$\begin{array}{l}\text { Exhaust } \\
\text { emissions }\end{array}$} & No & 427 & $72.62 \%$ \\
\hline & & Yes & 161 & $27.38 \%$ \\
\hline \multirow{6}{*}{ occ } & \multirow{6}{*}{ Occupation } & $\begin{array}{l}\text { Agriculture, forestry } \\
\text { and fishing }\end{array}$ & 43 & $7.54 \%$ \\
\hline & & Manufacturing & 75 & $13.16 \%$ \\
\hline & & Services & 181 & $31.75 \%$ \\
\hline & & Student & 228 & $40.00 \%$ \\
\hline & & Unemployed & 34 & $5.96 \%$ \\
\hline & & Retired & 9 & $1.58 \%$ \\
\hline
\end{tabular}

As shown in Table 1, nearly half (49.06\%) of the respondents said they had never heard of the Three-Year Action Plan for Winning the Blue Sky War. Seventy-two percent of the respondents said it was a necessary project for controlling the atmospheric environment, while only approximately one-tenth of the respondents said it was not necessary. However, with regard to the urgency of air control, two-thirds (66.2\%) of the respondents said they did not care about it. This may be related to the fact that the air quality of the interviewees living environments was relatively stable and of high quality, which had an impact on perceptions of the urgency of governance.

Through the air quality satisfaction survey in Table 2, we found that $46 \%$ of the respondents said that the air quality was fair and that approximately $22 \%$ of the respondents 
said that they were satisfied (including relatively satisfied and very satisfied), while $26 \%$ of the respondents said that they were not satisfied with the local air quality, and $6 \%$ of the respondents said that they were very dissatisfied. This shows that air quality in Zhejiang Province was considered generally stable, but that there was still room for improvement. Due to the asymmetry in the spatial distribution of air pollution, some areas with poor air quality should be managed.

Table 2. Environmental awareness.

\begin{tabular}{|c|c|c|c|c|}
\hline Symbol & Variables & Description & Frequency & Proportion \\
\hline know & $\begin{array}{l}\text { Cognitive } \\
\text { competence }\end{array}$ & $\begin{array}{l}\text { I have not heard of the } \\
\text { Blue Sky Battle Plan } \\
\text { I have heard of the } \\
\text { Blue Sky Battle Plan, } \\
\text { but I do not know } \\
\text { much about it } \\
\text { I understand the Blue } \\
\text { Sky Battle Plan }\end{array}$ & 252 & $\begin{array}{l}42.78 \% \\
8.15 \%\end{array}$ \\
\hline necessity & $\begin{array}{c}\text { Necessity of } \\
\text { environmental } \\
\text { governance }\end{array}$ & $\begin{array}{c}\text { At present it is } \\
\text { necessary } \\
\text { It will be necessary in } \\
\text { the future } \\
\text { It is not necessary }\end{array}$ & $\begin{array}{l}426 \\
86 \\
78\end{array}$ & $\begin{array}{l}72.20 \% \\
14.58 \% \\
13.22 \%\end{array}$ \\
\hline urg & $\begin{array}{c}\text { Urgency of } \\
\text { environmental } \\
\text { governance }\end{array}$ & $\begin{array}{c}\text { Do not need to } \\
\text { improve } \\
\text { Not urgent } \\
\text { It does not matter } \\
\text { Urgent } \\
\text { Very urgent }\end{array}$ & $\begin{array}{c}16 . \\
28 \\
346 \\
192 \\
8\end{array}$ & $\begin{array}{c}2.71 \% \\
4.75 \% \\
58.64 \% \\
32.54 \% \\
1.36 \%\end{array}$ \\
\hline
\end{tabular}

The setting of the effective labor supply is shown in Table 3. Residents' responses regarding air quality satisfaction, medical insurance, and expectations for the future in terms of life satisfaction, health, and labor participation were unified into a measure of effective labor supply. Considering the objectivity and comparability, this study adopted the average weighting method to construct the index. We assigned a value of 1-5 to the comprehensive index of labor, where 5 represented a low effective supply of labor.

Table 3. Effective labor supply.

\begin{tabular}{cc}
\hline Variable Name & $\begin{array}{c}\text { Definition } \\
\text { Ml }\end{array}$ \\
\hline Health & $\begin{array}{r}\text { This variable represented the expected mobility of residents over the next three years. The variable ranged } \\
\text { from 1-5 (low to high) and indicated the change in the respondent's willingness to settle down from high to } \\
\text { low. The variable was standardized to improve its comparability. } \\
\text { standardized the number of family members to form a new and more comparable variable. }\end{array}$ \\
\hline Medicalinsurance & $\begin{array}{c}\text { This variable represented the number of people in the respondent's family who had purchased medical } \\
\text { insurance. We standardized the number of family members to form a new and more comparable variable. }\end{array}$ \\
\hline Sat & $\begin{array}{r}\text { This variable represented the respondent's satisfaction with air quality. The variable ranged from 1-5 (low to } \\
\text { high) and represented the change in the respondent's satisfaction with air quality from high to low. The } \\
\text { variable was standardized to form a more comparable variable. }\end{array}$ \\
\hline Lfpr & $\begin{array}{c}\text { This variable indicated whether the respondent had been absent from work due to air quality problems. } \\
\text { Labor }\end{array}$ \\
$\begin{array}{c}\text { This is the variable that was explained in this study, which was weighted according to the average of the above } \\
\text { five indicators. The variable ranged from 1-5. From low to high, it meant that the greater the influence of air } \\
\text { quality on residents, the lower the supply of labor. }\end{array}$ \\
\hline
\end{tabular}




\section{Method and Result Discussion}

\subsection{Model}

4.1.1. Linear Probability Model (LPM)

$$
\begin{gathered}
\text { Labor }_{i}=C_{i}+\beta_{1} A Q I_{i}+\beta_{2} \text { age }_{i}+\beta_{3} \text { wp }_{i}+\beta_{4} \text { edu } \\
+\beta_{7} \text { know }_{i}+\beta_{5} \text { fluegas }_{i}+\beta_{9} \text { urg }_{i}+\beta_{10} \text { necessity }_{i}+\beta_{11} \text { occ }_{i} \\
+\beta_{12} \text { pt }_{i}+\beta_{13} \text { time }_{i}+\mu_{i}
\end{gathered}
$$

The explained variable, Labor, was the comprehensive index we constructed to measure the effective supply of labor. This study constructed a new comprehensive index to measure the labor supply by means of an average weighting method utilizing the five indexes of residents' lifestyle in next three years, the purchase of medical insurance, life satisfaction, health level, and labor participation rate. Disadvantages of the LPM for these dependent variables are obvious; however, the LPM has less restriction on the disturbance term and the result is more robust. Thus, the LPM model is presented here for comparison.

The explanatory variable was the air quality index $(A Q I)$ on the survey day. According to the definition of the statistic, the higher the air quality index is, the worse the local air quality is. Control variables were introduced to obtain unbiased or consistent estimates of core explanatory variables. The control variables for the individual characteristics of the residents included age (age), workplace $(w p)$, educational degree $(e d u)$, family income (income), family population (pop), environmental knowledge (know), emissions (fluegas), governance, the urgency of air control (urg), the necessity of air treatment (necessity), occupation $(o c c)$, census registration seat $(h t)$, and time spent at home each month (time); $\mu_{i}$ was the random disturbance term. This study chose these control variables for two reasons. Firstly, they are supported by the existing theories and literatures. The references corresponding to the control variables are shown in Appendix B. In the statistical sense, those are factors that may affect both the explained variable and the explanatory variable. Once these variables were omitted, endogenous problems might have been caused; so, for the sake of caution, we chose as many control variables as possible. The descriptive statistics of the samples are shown in Appendix C.

\subsubsection{Ordered Logit Model}

The variable selection gradient did not satisfy the assumptions that were necessary for a general linear regression analysis to explain the variable values and also violated the basic conditions for the general regression analysis method. There was no way to directly use a general regression model or a binary logistic regression model for the empirical analysis. An ordered logistic regression model was used in this analysis and the ordered probit model was also introduced as a reference. The general formula for an ordered logistic regression model is as follows:

$$
\operatorname{Logit}_{j}=\ln \left(\frac{p_{j}}{1-p_{j}}\right)=\alpha_{j}+\beta_{1} x_{1}+\beta_{2} x_{2}+\ldots \beta_{n} x_{n} p_{j}=p(y \leq j \mid x)
$$

is the cumulative probability of $y$ taking on the first $j$ values. The cumulative probability function is:

$$
p_{j}=p(y \leq j \mid x)=\left\{\begin{array}{cl}
\frac{\exp (a j+b x)}{1+\exp (a j+b x)}, & 1 \leq j \leq k-1 \\
1, & , j=k
\end{array}\right.
$$

\subsubsection{Heckman Sample Selection Model}

Due to the conditions of the actual investigation process, the samples could not be perfectly randomly selected. There might have been a truncation problem, so a sample selection model was used in the analysis. The main value of the sample selection model was that it could effectively correct for sample selectivity bias, which could not be eliminated 
through a sampling design of $y_{i}=y_{i} * d_{i}$. The basic structure of the sample selection model is as follows:

$$
\begin{gathered}
y_{i}^{*}=x_{i}^{\prime} \beta+\varepsilon_{i}, i=1, \ldots, n \\
d_{i}^{*}=z_{i}^{\prime} \gamma+v_{i}, i=1, \ldots, n \\
d_{i}=\left\{\begin{array}{c}
1\left(d_{i}^{*} \geq c\right) \\
0\left(d_{i}^{*} \leq c\right)
\end{array}\right. \\
y_{i}=y_{i}^{*} d_{i}
\end{gathered}
$$

Equation (1) is the theoretical result equation, Equation (2) is a selection equation in which the variable being explained cannot be observed, and Equations (3) and (4) reflect the correspondence between $d_{i}$ and $d_{i}^{*}$ and $y_{i}$ and $y_{i}^{*}$, respectively. The sample selection model requires $\varepsilon_{i}$ and $v_{i}$ to be correlated and $E\left[\varepsilon_{i} \mid v_{i}\right] \neq 0$. Using the sample selection model, we mainly considered that the answers to the questionnaire might not have been random. If there were sample selection problems, we could have used the sample selection model to reduce the selectivity bias, and the results could have been used as a reference.

\subsection{Discussion of Results}

The effective supply of labor is significantly correlated with air quality (Table 4). This shows that when the air quality is worse, the effective supply of labor is lower. When air quality impedes residents' daily life and even affects their health, it indirectly affects the effective supply of local labor. The effective supply of labor is significantly negatively correlated with respondents' working environment (indoor vs. outdoor) in our data. Given the arrangement "indoor $=1$, outdoor $=2$ ", the negative correlation indicates that residents who work outdoors are exposed to air more frequently and for longer periods and suffer more seriously from air pollution. However, this relationship is not robust and is clearer for participants who worked indoors because there were too few participants who worked outdoors in this study (Please refer to Appendix D for further explanation). Compared with indoor air quality, outdoor air quality is worse. Household size (pop) and occupation (occ) were significantly negatively correlated with the effective supply of labor, and residents' environmental awareness (know) and household registration ( $h t$ ) were significantly positively correlated.

The ordered logit model results show that the effective supply of labor is significantly positively related to the air quality index. When air quality problems have a greater negative impact on residents' life and health, it not only affects the transportation of residents but also has a significant influence on people's physical and mental health. For their own protection, people ask for leave to reduce travel or work, which reduces the labor participation rate and reduces the effective supply of labor. In addition, the effective supply of labor is significantly correlated with the respondents' working environment (indoor vs. outdoor), number of family members (pop), level of awareness (know), and household registration location $(h t)$. The size of a family and the respondents' awareness of environmental pollution largely affect the effective supply of labor. The larger the respondent's family is or the higher the respondent's awareness of environmental protection is, the lower the effective supply of labor.

The results of the sample selection model show that the effective supply of labor is significantly positively correlated with the air quality index. In addition, the effective supply of labor is significantly correlated with the respondent's working environment (indoor vs. outdoor), number of family members (pop), level of awareness (know), and household registration location $(h t)$. This indicates that when the air quality worsens, residents' effective supply of labor decreases. This finding is consistent with the above results. 
Table 4. Regression results of air quality index (AQI) on the effective labor supply.

\begin{tabular}{|c|c|c|c|c|}
\hline & (1) & (2) & (3) & (3) \\
\hline & OLS & Ologit & Oprobit & Heckman \\
\hline Variable & Labor & Labor & Labor & Labor \\
\hline aqi & $\begin{array}{c}0.0099 * * * \\
(0.0026)\end{array}$ & $\begin{array}{c}0.0397^{* * *} \\
(0.0084)\end{array}$ & $\begin{array}{c}0.0219 * * * \\
(0.0049)\end{array}$ & $\begin{array}{c}0.0076^{* * * *} \\
(0.0014)\end{array}$ \\
\hline age & $\begin{array}{c}0.0065 \\
(0.0240)\end{array}$ & $\begin{array}{l}-0.0539 \\
(0.0778)\end{array}$ & $\begin{array}{l}-0.0141 \\
(0.0417)\end{array}$ & $\begin{array}{c}0.0041 \\
(0.0206)\end{array}$ \\
\hline wp & $\begin{array}{c}-0.2434^{* *} \\
(0.0982)\end{array}$ & $\begin{array}{c}-0.5881 * \\
(0.3278)\end{array}$ & $\begin{array}{c}-0.3815^{* *} \\
(0.1765)\end{array}$ & $\begin{array}{c}-0.2441 \text { ** } \\
(0.0990)\end{array}$ \\
\hline edu & $\begin{array}{c}0.0245 \\
(0.0368)\end{array}$ & $\begin{array}{c}0.1420 \\
(0.1230)\end{array}$ & $\begin{array}{c}0.0819 \\
(0.0629)\end{array}$ & $\begin{array}{c}0.0223 \\
(0.0331)\end{array}$ \\
\hline income & $\begin{array}{c}0.0204 \\
(0.0271)\end{array}$ & $\begin{array}{c}0.1080 \\
(0.0914)\end{array}$ & $\begin{array}{c}0.0351 \\
(0.0491)\end{array}$ & $\begin{array}{l}-0.0096 \\
(0.0314)\end{array}$ \\
\hline pop & $\begin{array}{c}-0.1414^{* * *} \\
(0.0269)\end{array}$ & $\begin{array}{c}-0.3881^{* * *} \\
(0.0818)\end{array}$ & $\begin{array}{c}-0.2068^{* * *} \\
(0.0424)\end{array}$ & $\begin{aligned} &-0.0793 * * * \\
&(0.0244)\end{aligned}$ \\
\hline know & $\begin{array}{c}0.1129 * * * \\
(0.0413)\end{array}$ & $\begin{array}{l}0.3495 * * \\
(0.1410)\end{array}$ & $\begin{array}{c}0.2041 * * * \\
(0.0752)\end{array}$ & $\begin{array}{l}0.0892 * * \\
(0.0355)\end{array}$ \\
\hline fluegas & $\begin{array}{c}0.0276 \\
(0.0587)\end{array}$ & $\begin{array}{c}0.1231 \\
(0.1777)\end{array}$ & $\begin{array}{c}0.1043 \\
(0.0992)\end{array}$ & $\begin{array}{c}0.0688 \\
(0.0555)\end{array}$ \\
\hline urg & $\begin{array}{l}-0.0241 \\
(0.0396)\end{array}$ & $\begin{array}{l}-0.1248 \\
(0.1336)\end{array}$ & $\begin{array}{l}-0.0817 \\
(0.0686)\end{array}$ & $\begin{array}{l}-0.0463 \\
(0.0355)\end{array}$ \\
\hline necessity & $\begin{array}{c}0.0401 \\
(0.0385)\end{array}$ & $\begin{array}{c}0.1859 \\
(0.1354)\end{array}$ & $\begin{array}{c}0.0737 \\
(0.0726)\end{array}$ & $\begin{array}{c}0.0071 \\
(0.0366)\end{array}$ \\
\hline occ & $\begin{array}{c}-0.1032 * * * \\
(0.0304)\end{array}$ & $\begin{array}{c}-0.2967^{* * *} \\
(0.1014)\end{array}$ & $\begin{array}{c}-0.1771 \text { *** } \\
(0.0541)\end{array}$ & $\begin{array}{l}-0.1103^{* * * *} \\
(0.0264)\end{array}$ \\
\hline ht & $\begin{array}{c}0.0696^{* * *} \\
(0.0230)\end{array}$ & $\begin{array}{c}0.2472 * * * \\
(0.0729)\end{array}$ & $\begin{array}{c}0.1290^{* * *} \\
(0.0400)\end{array}$ & $\begin{array}{l}0.0427 * \\
(0.0221)\end{array}$ \\
\hline time & $\begin{array}{l}-0.0150 \\
(0.0114)\end{array}$ & $\begin{array}{l}-0.0411 \\
(0.0393)\end{array}$ & $\begin{array}{l}-0.0225 \\
(0.0208)\end{array}$ & $\begin{array}{l}-0.0105 \\
(0.0120)\end{array}$ \\
\hline Constant & $\begin{array}{c}2.1716^{* * *} \\
(0.3276)\end{array}$ & & & $\begin{array}{c}2.2060^{* * * *} \\
(0.3088)\end{array}$ \\
\hline $\begin{array}{c}\text { Obs. } \\
\text { R-squared }\end{array}$ & $\begin{array}{c}494 \\
0.2262\end{array}$ & 494 & 494 & 539 \\
\hline
\end{tabular}
Note: Robust standard errors in parentheses. ${ }^{* * *} p<0.01,{ }^{* *} p<0.05,{ }^{*} p<0.1$.

The results of these three models are very consistent, which indicates the accuracy and uniformity of the results of this study. It also strengthens the reliability of the finding that air quality problems have a negative impact on the effective supply of labor.

The result of a robustness test using a stepwise regression is presented in Table 5. With each variable added to the test, the effective supply of labor and the air quality index remain significantly positively related. In addition, the effective supply of labor and the working environment (indoor vs. outdoor), family size (pop), and level of awareness (know) are significantly related to census registration seat $(h t)$. The variables were added step by step, and the results are the same as before. The possible interactions are also examined, the results show that this study are robust (Appendix E: Table A5). 
Table 5. Robustness test.

\begin{tabular}{|c|c|c|c|c|c|c|}
\hline & (1) & (2) & (3) & (4) & (5) & (6) \\
\hline Variable & Labor & Labor & Labor & Labor & Labor & Labor \\
\hline \multirow[t]{2}{*}{ aqi } & $0.0090^{* * *}$ & $0.0093^{* * *}$ & $0.0101^{* * *}$ & $0.0105^{* * *}$ & $0.0099 * * *$ & $0.0099 * * *$ \\
\hline & $(0.0023)$ & $(0.0024)$ & $(0.0024)$ & $(0.0024)$ & $(0.0025)$ & $(0.0026)$ \\
\hline \multirow[t]{2}{*}{ age } & -0.0024 & -0.0019 & -0.0009 & 0.0057 & 0.0052 & 0.0065 \\
\hline & $(0.0246)$ & $(0.0246)$ & $(0.0244)$ & $(0.0242)$ & $(0.0241)$ & $(0.0240)$ \\
\hline \multirow[t]{2}{*}{ wp } & -0.0920 & -0.0926 & -0.0987 & $-0.2391^{* *}$ & $-0.2306^{* *}$ & $-0.2434^{* *}$ \\
\hline & $(0.0827)$ & $(0.0824)$ & $(0.0819)$ & $(0.0980)$ & $(0.0974)$ & $(0.0982)$ \\
\hline \multirow[t]{2}{*}{ edu } & 0.0274 & 0.0286 & 0.0351 & 0.0395 & 0.0336 & 0.0245 \\
\hline & $(0.0365)$ & $(0.0367)$ & $(0.0364)$ & $(0.0363)$ & $(0.0362)$ & $(0.0368)$ \\
\hline \multirow[t]{2}{*}{ income } & 0.0187 & 0.0210 & 0.0100 & 0.0160 & 0.0161 & 0.0204 \\
\hline & $(0.0274)$ & $(0.0277)$ & $(0.0279)$ & $(0.0274)$ & $(0.0268)$ & $(0.0271)$ \\
\hline \multirow[t]{2}{*}{ pop } & $-0.1567^{* * *}$ & $-0.1567^{* * *}$ & $-0.1579^{* * *}$ & $-0.1482^{* * *}$ & $-0.1437^{* * *}$ & $-0.1414^{* * *}$ \\
\hline & $(0.0273)$ & $(0.0272)$ & $(0.0273)$ & $(0.0265)$ & $(0.0267)$ & $(0.0269)$ \\
\hline \multirow[t]{2}{*}{ know } & $0.1354 * * *$ & $0.1351^{* * *}$ & $0.1379 * * *$ & $0.1238^{* * *}$ & $0.1164^{* * *}$ & $0.1129 * * *$ \\
\hline & $(0.0428)$ & $(0.0428)$ & $(0.0426)$ & $(0.0423)$ & $(0.0412)$ & $(0.0413)$ \\
\hline \multirow[t]{2}{*}{ fluegas } & 0.0278 & 0.0333 & 0.0350 & 0.0143 & 0.0330 & 0.0276 \\
\hline & $(0.0598)$ & $(0.0597)$ & $(0.0595)$ & $(0.0600)$ & $(0.0587)$ & $(0.0587)$ \\
\hline \multirow[t]{2}{*}{ urg } & & -0.0358 & -0.0307 & -0.0282 & -0.0290 & -0.0241 \\
\hline & & $(0.0402)$ & $(0.0400)$ & $(0.0397)$ & $(0.0393)$ & $(0.0396)$ \\
\hline \multirow[t]{2}{*}{ necessity } & & & 0.0762 * & 0.0674 * & 0.0402 & 0.0401 \\
\hline & & & $(0.0392)$ & $(0.0389)$ & $(0.0387)$ & $(0.0385)$ \\
\hline \multirow[t]{2}{*}{ occ } & & & & $-0.1011^{* * *}$ & $-0.0989^{* * *}$ & $-0.1032^{* * *}$ \\
\hline & & & & $(0.0300)$ & $(0.0299)$ & $(0.0304)$ \\
\hline \multirow[t]{2}{*}{ ht } & & & & & $0.0696^{* * *}$ & $0.0696^{* * *}$ \\
\hline & & & & & $(0.0228)$ & $(0.0230)$ \\
\hline \multirow[t]{2}{*}{ time } & & & & & & -0.0150 \\
\hline & & & & & & $(0.0114)$ \\
\hline \multirow[t]{2}{*}{ Constant } & $1.8017^{* * *}$ & $1.9024^{* * *}$ & $1.7592 * * *$ & $2.1600 * * *$ & $2.0958^{* * *}$ & $2.1716^{* * *}$ \\
\hline & $(0.2671)$ & $(0.2909)$ & $(0.2973)$ & $(0.3198)$ & $(0.3185)$ & $(0.3276)$ \\
\hline Obs. & 504 & 504 & 504 & 496 & 496 & 494 \\
\hline R-squared & 0.1846 & 0.1860 & 0.1917 & 0.2084 & 0.2234 & 0.2262 \\
\hline
\end{tabular}

Note: Robust standard errors in parentheses. ${ }^{* * *} p<0.01,{ }^{* *} p<0.05,{ }^{*} p<0.1$.

\subsection{Heterogeneity Test}

This study made a consistent analysis of the impact of air quality on the labor supply. Table 6 shows that among the respondents aged 21-30, air quality has a significant impact on labor supply. This may be because respondents in this age group have higher levels of environmental awareness and self-protection awareness and would rather ask for leave than expose themselves to air pollution when faced with poor air conditions. There was some heterogeneity by age in the other influencing factors. Table 7 shows the heterogeneity analysis based on our survey regions: Hangzhou, Jinhua, Ningbo, Jiaxing, and Huzhou. The results in the first three columns show that air quality has a significant impact on labor supply; that is, the influence of air quality in the regions of Hangzhou, Ningbo, and Huzhou is even more significant. This may be due to their local economic development, their industrial structure, and their geographical boundaries, which lead to more serious air pollution problems. However, it is also possible that because of their more developed economic level, local residents' environmental awareness is higher, giving them a stronger sense of self-protection. 
Table 6. Heterogeneity analysis—by age.

\begin{tabular}{|c|c|c|c|c|c|}
\hline & (1) & (2) & (3) & (4) & (5) \\
\hline Variable & Labor & Labor & Labor & Labor & Labor \\
\hline \multirow[t]{2}{*}{ aqi } & $0.0108^{* *}$ & $0.0098^{* * *}$ & $0.0169^{* *}$ & 0.0073 & 0.0090 \\
\hline & $(0.0052)$ & $(0.0037)$ & $(0.0081)$ & $(0.0118)$ & $(0.0118)$ \\
\hline \multirow[t]{2}{*}{ age } & -0.0669 & $0.0900^{* *}$ & $-0.1283^{* * * *}$ & 0.0633 & 0.0456 \\
\hline & $(0.0597)$ & $(0.0436)$ & $(0.0404)$ & $(0.0626)$ & $(0.0852)$ \\
\hline \multirow[t]{2}{*}{ wp } & 0.0090 & $-0.3191^{* *}$ & -0.3148 & $0.4009^{* *}$ & -0.3145 \\
\hline & $(0.3037)$ & $(0.1607)$ & $(0.2030)$ & $(0.1716)$ & $(0.3098)$ \\
\hline \multirow[t]{2}{*}{ edu } & 0.0126 & 0.0188 & 0.0560 & -0.0618 & 0.0443 \\
\hline & $(0.1204)$ & $(0.0610)$ & $(0.0577)$ & $(0.1801)$ & $(0.1329)$ \\
\hline \multirow[t]{2}{*}{ income } & -0.0348 & 0.0725 & -0.0272 & 0.0859 & -0.0357 \\
\hline & $(0.0837)$ & $(0.0556)$ & $(0.0584)$ & $(0.0693)$ & $(0.0826)$ \\
\hline \multirow[t]{2}{*}{ pop } & $-0.1583^{*}$ & $-0.1652^{* * *}$ & $-0.1528^{* * *}$ & -0.1052 & -0.0931 \\
\hline & $(0.0867)$ & $(0.0421)$ & $(0.0493)$ & $(0.0951)$ & $(0.0778)$ \\
\hline \multirow[t]{2}{*}{ know } & 0.1926 & 0.0353 & 0.0998 & 0.2909 * & -0.0189 \\
\hline & $(0.1188)$ & $(0.0715)$ & $(0.0974)$ & $(0.1533)$ & $(0.1590)$ \\
\hline \multirow{2}{*}{ fluegas } & -0.1593 & -0.0204 & $0.2721^{* *}$ & 0.0415 & 0.1935 \\
\hline & $(0.1588)$ & $(0.0978)$ & $(0.1303)$ & $(0.2192)$ & $(0.2202)$ \\
\hline \multirow[t]{2}{*}{ urg } & 0.0173 & -0.0641 & 0.0268 & -0.0335 & 0.0600 \\
\hline & $(0.0919)$ & $(0.0708)$ & $(0.0926)$ & $(0.1142)$ & $(0.2127)$ \\
\hline \multirow[t]{2}{*}{ necessity } & 0.0239 & 0.0615 & -0.0539 & -0.0563 & -0.0740 \\
\hline & $(0.1037)$ & $(0.0534)$ & $(0.1428)$ & $(0.1759)$ & $(0.2424)$ \\
\hline \multirow[t]{2}{*}{ occ } & -0.1460 * & $-0.1344^{* *}$ & 0.0662 & -0.0089 & -0.1643 * \\
\hline & $(0.0779)$ & $(0.0522)$ & $(0.0660)$ & $(0.0935)$ & $(0.0826)$ \\
\hline \multirow[t]{2}{*}{ ht } & 0.0459 & $0.0734^{* *}$ & $0.1144^{* *}$ & 0.0251 & 0.1345 \\
\hline & $(0.0505)$ & $(0.0362)$ & $(0.0503)$ & $(0.0647)$ & $(0.1470)$ \\
\hline \multirow[t]{2}{*}{ time } & -0.0621 & -0.0061 & -0.0306 & -0.0031 & -0.0182 \\
\hline & $(0.0608)$ & $(0.0346)$ & $(0.0436)$ & $(0.0154)$ & $(0.0506)$ \\
\hline \multirow[t]{2}{*}{ Constant } & $2.4246^{* * *}$ & $2.3375^{* * *}$ & $1.5545^{* *}$ & 1.0739 & $2.2679 * *$ \\
\hline & $(0.9089)$ & $(0.6034)$ & $(0.6766)$ & $(1.1353)$ & $(0.9551)$ \\
\hline Observations & 92 & 200 & 101 & 51 & 50 \\
\hline R-squared & 0.2692 & 0.3171 & 0.2970 & 0.3011 & 0.1879 \\
\hline
\end{tabular}

Note: Robust standard errors in parentheses. ${ }^{* * *} p<0.01,{ }^{* *} p<0.05,{ }^{*} p<0.1$.

Table 7. Heterogeneity analysis—by region.

\begin{tabular}{|c|c|c|c|c|c|}
\hline & (1) & (2) & (3) & (4) & (5) \\
\hline Variable & Labor & Labor & Labor & Labor & Labor \\
\hline aqi & $\begin{array}{l}0.0098^{* *} \\
(0.0041)\end{array}$ & $\begin{array}{c}0.0105^{* * *} \\
(0.0022)\end{array}$ & $\begin{array}{l}0.0294^{* *} \\
(0.0118)\end{array}$ & $\begin{array}{l}-0.0107 \\
(0.0139)\end{array}$ & $\begin{array}{c}0.0164 \\
(0.0098)\end{array}$ \\
\hline age & $\begin{array}{c}0.0528 \\
(0.0409)\end{array}$ & $\begin{array}{c}0.0367 \\
(0.0360)\end{array}$ & $\begin{array}{l}-0.0805 \\
(0.0585)\end{array}$ & $\begin{array}{c}0.0502 \\
(0.0839)\end{array}$ & $\begin{array}{c}0.0130 \\
(0.0651)\end{array}$ \\
\hline wp & $\begin{array}{c}-0.3285^{* *} \\
(0.1527)\end{array}$ & $\begin{array}{c}0.0134 \\
(0.1731)\end{array}$ & $\begin{array}{l}-0.4375 \\
(0.5016)\end{array}$ & $\begin{array}{c}-0.6211 \text { * } \\
(0.3395)\end{array}$ & $\begin{array}{l}-0.2098 \\
(0.2403)\end{array}$ \\
\hline edu & $\begin{array}{l}-0.0588 \\
(0.0748)\end{array}$ & $\begin{array}{l}0.1118 \text { ** } \\
(0.0444)\end{array}$ & $\begin{array}{c}0.0490 \\
(0.0948)\end{array}$ & $\begin{array}{c}0.0304 \\
(0.1464)\end{array}$ & $\begin{array}{l}-0.0920 \\
(0.1165)\end{array}$ \\
\hline income & $\begin{array}{c}0.0670 \\
(0.0485)\end{array}$ & $\begin{array}{c}0.0760 \\
(0.0555)\end{array}$ & $\begin{array}{c}0.1042 \\
(0.0773)\end{array}$ & $\begin{array}{c}-0.1465 \text { * } \\
(0.0754)\end{array}$ & $\begin{array}{c}0.0169 \\
(0.0688)\end{array}$ \\
\hline pop & $\begin{array}{c}-0.1859 * * * \\
(0.0436)\end{array}$ & $\begin{array}{c}-0.0944^{* * *} \\
(0.0334)\end{array}$ & $\begin{array}{l}-0.0874 \\
(0.0797)\end{array}$ & $\begin{array}{l}-0.1255 \\
(0.0888)\end{array}$ & $\begin{array}{l}-0.0656 \\
(0.0619)\end{array}$ \\
\hline know & $\begin{array}{c}0.0919 \\
(0.0616)\end{array}$ & $\begin{array}{c}0.0300 \\
(0.0699)\end{array}$ & $\begin{array}{c}0.1336 \\
(0.1438)\end{array}$ & $\begin{array}{l}0.2938^{*} \\
(0.1656)\end{array}$ & $\begin{array}{c}0.0361 \\
(0.1357)\end{array}$ \\
\hline
\end{tabular}


Table 7. Cont.

\begin{tabular}{|c|c|c|c|c|c|}
\hline & (1) & (2) & (3) & (4) & (5) \\
\hline Variable & Labor & Labor & Labor & Labor & Labor \\
\hline \multirow[t]{2}{*}{ fluegas } & 0.0189 & -0.0517 & $0.4366^{* *}$ & -0.0350 & 0.0780 \\
\hline & $(0.1041)$ & $(0.0899)$ & $(0.1861)$ & $(0.1885)$ & $(0.1655)$ \\
\hline \multirow{2}{*}{ urg } & -0.0316 & -0.0478 & -0.0898 & 0.1330 & 0.0318 \\
\hline & $(0.0570)$ & $(0.0939)$ & $(0.1024)$ & $(0.1364)$ & $(0.1915)$ \\
\hline \multirow[t]{2}{*}{ necessity } & -0.0353 & $0.1389 *$ & $-0.4237^{* *}$ & -0.1321 & -0.0622 \\
\hline & $(0.0573)$ & $(0.0723)$ & $(0.1905)$ & $(0.2746)$ & $(0.1886)$ \\
\hline \multirow[t]{2}{*}{ occ } & $-0.1345^{* * *}$ & -0.0325 & 0.0610 & -0.0372 & $-0.1603^{* *}$ \\
\hline & $(0.0488)$ & $(0.0388)$ & $(0.0748)$ & $(0.0958)$ & $(0.0696)$ \\
\hline \multirow[t]{2}{*}{ ht } & 0.0205 & $0.1582^{* * *}$ & $0.1044 *$ & 0.1509 * & $0.2485 *$ \\
\hline & $(0.0338)$ & $(0.0498)$ & $(0.0623)$ & $(0.0820)$ & $(0.1249)$ \\
\hline \multirow[t]{2}{*}{ time } & -0.0326 & -0.0022 & -0.0859 & 0.0168 & $-0.0201^{*}$ \\
\hline & $(0.0343)$ & $(0.0349)$ & $(0.0614)$ & $(0.0430)$ & $(0.0112)$ \\
\hline \multirow[t]{2}{*}{ Constant } & $3.0632 * * *$ & 0.6521 & 1.4273 & $2.4706^{* *}$ & $2.1631 * *$ \\
\hline & $(0.5443)$ & $(0.6575)$ & (1.1288) & $(1.1702)$ & $(0.8595)$ \\
\hline Observations & 226 & 87 & 65 & 51 & 65 \\
\hline R-squared & 0.2587 & 0.4112 & 0.3566 & 0.3645 & 0.2203 \\
\hline
\end{tabular}

Note: Robust standard errors in parentheses. ${ }^{* *} p<0.01,{ }^{* *} p<0.05,{ }^{*} p<0.1$.

\section{Conclusions}

Air quality issues have a negative impact on health and affect the quality and quantity of labor, which directly affects the effective supply of labor and labor participation rates. We find that the worse the air quality is, the lower the effective supply of labor. This may be because poor air quality limits residents' travel. For example, haze often occurs in Zhejiang Province in winter and reduces visibility, greatly limiting people's travel. Additionally, haze also harms the health of residents, and long-term inhalation of pollutant particles induces respiratory tract infections and other related diseases [23-26]. In addition, air pollution will affect the supply of labor through the mechanism of residents' happiness [37,38,43]. Due to such bad air quality, most residents choose to ask for leave for their own selfprotection, as it is safer to reduce working hours. From the perspective of the family, the immunity of the elderly members and the children in the family is weaker than that of the adults, and they are more likely to get sick due to poor air quality. Workers need to spend more time taking care of their families, thus reducing their hours supplied and affecting the effective supply of labor [9]. The effect of air pollution on the demand for medical insurance is mainly observed for women, children, the elderly, and people with high income and educational levels, all of whom are more likely to adopt avoidance behaviors [14]. In addition, there is a significant and negative effect of air pollution on migrants' interest in settling down. Air pollution undermines investment in human capital and may become an obstacle to the sustainable development of cities [8]. This is consistent with our research: the shortage of human capital mainly refers to the shortage of an effective labor supply. At the same time, studies have shown that when air quality gets worse (a $20 \%$ increase in sulfur dioxide levels), work hours are reduced by $1.3 \mathrm{~h}$ the following week. But many low-income countries are reluctant to sacrifice economic benefits for environmental regulation. Additionally, the availability of labor matters, which can make up for the loss of this aspect [2]. At the same time, our results are very robust. We also conducted a heterogeneity analysis by age and region, which shows that differences in the awareness of air quality issues and exposure to air pollution among those of different ages and in different regions have an impact on the supply of labor. By age, people aged between 21 and 30 years are more likely to not go to work because of air quality problems. Pollution is more severe in border areas and more economically developed areas, and the labor supply of local residents is more likely to be affected by air quality problems. This is of significant reference value for the government in formulating environment-related policies, clarifying the important mechanisms affecting human health, and paying more 
attention to the idea of building a livable society and green homes. Additionally, differences between regions should receive attention, and the air environment should be controlled according to the characteristics of local development [44]. Finally, focusing on people who are older or who have less access to social information allows them to strengthen their environmental education, their awareness of environmental protection, and their awareness of the importance of self-protection.

For the government, the first step is to optimize urban economic development. A low pollution and low energy consumption way of production and life should be adhered to. The coordinated development of economic growth and environmental quality, which has a positive impact on people's life satisfaction, should be promoted. Air quality is an important aspect of people's livelihood and has become an important factor affecting people's sense of gain. To improve residents' environmental and life satisfaction, local governments at all levels should set improving air quality as a priority for development. Second, reasonable compensation measures should be determined. The government cannot simply impose fixed compensation standards on all residents, which may cause the policy to change from over-incentivizing to under-incentivizing green behaviors, which directly affects residents' enthusiasm for participating in programs for protecting the atmospheric environment. Therefore, the government can vary the compensation standards within a certain range, which is conducive to fully utilizing the reasonable incentive effects of ecological compensation and to avoiding the occurrence of extreme compensation. Therefore, environmental protection policies should be formulated according to local conditions and for making environmental energy saving more and more important. The government should proceed based on reality, seek truth through facts, and formulate environmental protection policies for air quality in various regions on the basis of local conditions. In the process of setting up environmental protection policies, on the one hand, the government should carry out comprehensive treatments of damaged or polluted environments, and on the other hand, it should pay attention to preventively protecting the ecological environment. This is conducive to improving the efficiency of governance and building up the image of a responsible and responsive government. Finally, a foundation of public participation should be built. Increasing the publicity of environmental protection and raising residents' awareness of environmental protection through environmental education is very important, as is a successful transition from an administrative approach to a marketbased environmental approach. Our findings also reveal the importance of environmental awareness among family members. The government should work on raising public awareness of the importance of environmental improvement and on increasing participation in environmental protection initiatives, thus effectively improving the implementation of air quality improvement measures and encouraging more households to take action.

The reliability of this conclusion is limited by several conditions, although we tried to get more objective results. The representativeness of the sample was determined in the early stage of the questionnaire survey. Although this study adopted a multi-stage random sampling approach to randomize the sample as much as possible, it was not perfect. According to the characteristics of the sample, we found that there were some differences compared with the population characteristics of permanent residents in Zhejiang Province. For example, among those who answered the questionnaire, the outdoor sample size was smaller, which limited the conclusion of this study. There might have been selectivity bias, and the respondents were not randomly selected. Although we tried to use the sample selection model to reduce the error, it was far from enough. The second important issue is the limitation of using the AQI to represent air quality. We could only find AQI data from the air quality data of prefecture level cities on the day of questionnaire interview. If we could have gotten more specific micro level air pollution data, such as district and county level, or more air quality indicators, the estimation might have been more accurate. The third problem that might have caused the atypicality of this research is the events that were happening when the questionnaire was being administered. The survey period was from July to September 2020 when Zhejiang and the world were all affected by COVID-19, 
and the structure of labor demand and air quality all have particularities. As a result, the respondents' answers might have been atypical. A longer-term comparative survey is needed, such as conducting another questionnaire survey at the same time of the year and making a comparison. The last obvious deficiency is that this paper only used the outdoor $\mathrm{AQI}$ to measure the overall $\mathrm{AQI}$ and thus cannot accurately use the data to measure the difference between indoor and outdoor air quality. We used data from the environmental monitoring station on the day of the questionnaire interview to measure AQI, rather than measuring AQI ourselves. From the micro level, this is not perfect; however, there is no better alternative at present. From the current research's point of view, the direct use of outdoor air quality data to measure the overall level was a reasonable proxy. With the progress of technology and the improvement of research methods, this leaves open a space for further research.

There is some room for further research. First, although the scientific sampling was representative to a certain extent, the limited sample size and the error in respondents' answers cannot be avoided, which might have led to some deviation in the results. Second, we did not analyze the other indicators, which does not exclude the existence of other heterogeneity problems. Finally, in the study of air quality, we did not estimate the economic value of air quality, which lays a foundation for subsequent research.

Author Contributions: Conceptualization, Y.Y.; methodology, J.F. and W.W.; software, J.F. and Y.L. (Yan Li).; validation, J.F.; formal analysis, J.F.; investigation, Y.Y.; data curation, Y.L. (Yan Li); writing—original draft preparation, J.F. and W.W.; writing—review and editing, Y.Y.; visualization, J.F.; supervision, Y.L. (Yi Li); project administration, Y.L. (Yi Li); funding acquisition, Y.Y. All authors have read and agreed to the published version of the manuscript.

Funding: This research was funded by the National Social Science Fund of China (19AZD004), Science and Technology Innovation Activity Plan of College Students in Zhejiang Province (2020R406027), the National College Students' Innovative Entrepreneurial Training Program of China (202010338020), Scientific Research Fund of Zhejiang Provincial Education Department (20096120-F), Science Foundation of Zhejiang Sci-Tech University (18092252-Y), the General Project of Humanities and Social Sciences Research of the Ministry of Education of China (20YJC790090).

Institutional Review Board Statement: Not applicable.

Informed Consent Statement: Informed consent was obtained from all subjects involved in the study.

Data Availability Statement: Not applicable.

Acknowledgments: We greatly appreciate the help with data collection of Ziwei Liu and valuable help of Jing Wenin Zhejiang Sci-Tech University.

Conflicts of Interest: The authors declare no conflict of interest. The funders had no role in the design of the study; in the collection, analyses, or interpretation of data; in the writing of the manuscript; or in the decision to publish the results. 


\section{Appendix A}

Table A1. The content of the questionnaire.

\begin{tabular}{|c|c|c|}
\hline To Explore the Factors & Specific Topics & Set the Purpose \\
\hline \multirow{2}{*}{ Health } & $\begin{array}{l}\text { "Several members of your family } \\
\text { have related illnesses due to air } \\
\text { problems; several people died." }\end{array}$ & $\begin{array}{l}\text { Understand the impact of air } \\
\text { quality problems on the health } \\
\text { status of residents }\end{array}$ \\
\hline & $\begin{array}{c}\text { "Several of your close relatives have } \\
\text { suffered from diseases related to air } \\
\text { pollution, and some have died from } \\
\text { it." }\end{array}$ & $\begin{array}{l}\text { Expand the scope to } \\
\text { understand the impact of air } \\
\text { quality on residents' health }\end{array}$ \\
\hline \multirow{3}{*}{$\begin{array}{l}\text { Preventive } \\
\text { expenditure }\end{array}$} & $\begin{array}{l}\text { "How many people in your family } \\
\text { are paying for additional health } \\
\text { insurance?" }\end{array}$ & $\begin{array}{l}\text { Know the residents' } \\
\text { protection measures }\end{array}$ \\
\hline & $\begin{array}{l}\text { "If the air pollution cannot be } \\
\text { improved in the near future, what is } \\
\text { the minimum monthly compensation } \\
\text { you need?" }\end{array}$ & $\begin{array}{c}\text { On the one hand, it can show } \\
\text { the severity of air quality; on } \\
\text { the other hand, it can help } \\
\text { residents to protect } \\
\text { themselves }\end{array}$ \\
\hline & $\begin{array}{l}\text { "Air control is a project that requires } \\
\text { the participation of the whole society. } \\
\text { How much are you willing to spend } \\
\text { every month to improve the } \\
\text { environment?" }\end{array}$ & $\begin{array}{c}\text { It can reflect residents' } \\
\text { awareness of environmental } \\
\text { protection and the importance } \\
\text { of air pollution control }\end{array}$ \\
\hline Satisfaction & $\begin{array}{l}\text { "How satisfied are you with the local } \\
\text { air quality?" }\end{array}$ & $\begin{array}{l}\text { The side shows the state of } \\
\text { local air quality }\end{array}$ \\
\hline Individual mobility & $\begin{array}{c}\text { "How will you live here in the next } \\
\text { three years?" }\end{array}$ & $\begin{array}{c}\text { By asking residents how they } \\
\text { live, they can show how } \\
\text { satisfied they are with all } \\
\text { aspects of the place and the air } \\
\text { quality }\end{array}$ \\
\hline \multirow{5}{*}{ The basic information } & Your career & $\begin{array}{l}\text { Understand the relationship } \\
\text { between }\end{array}$ \\
\hline & Your age & $\begin{array}{l}\text { Determine sample } \\
\text { characteristics }\end{array}$ \\
\hline & Average annual family income & $\begin{array}{l}\text { Analyze the effect of income } \\
\text { and effective supply of } \\
\text { resident labor }\end{array}$ \\
\hline & The degree of education & $\begin{array}{l}\text { Analyze the relationship } \\
\text { between the two }\end{array}$ \\
\hline & The workplace & $\begin{array}{l}\text { Analyze the relationship } \\
\text { between the two }\end{array}$ \\
\hline
\end{tabular}




\section{Appendix B}

Table A2. Selection of control variables.

\begin{tabular}{cc}
\hline Control Variable & Related Research \\
\hline aqi & Qiu, H et al. (2020); Zhao, Y. et al. (2020) \\
age & Thomson, E.M. et al. (2020); Chen, F.; Chen, Z. (2020) \\
wp & Pu, S. et al. (2019); García-Mainar, I. et al. (2015) \\
edu & Chen, F.; Chen, Z. (2021); Chen, F.; Chen, Z. (2020) \\
income & Yang, T.; Liu, W. (2018); Chen, F.; Chen, Z. (2021) \\
pop & Freeman, R. et al. (2019); García-Mainar, I. et al. (2015) \\
know & Liu, Z.; Yu, L. (2020); Li, Z. et al. (2014) \\
fluegas & Li, Z. et al. (2014) \\
urg & Hanna, R.; Oliva, P. (2015); Shao, S. et al. (2018) \\
necessity & Hanna, R.; Oliva, P. (2015); Shao, S. et al. (2018) \\
occ & Zhang, X. et al. (2017); García-Mainar, I. et al. (2015) \\
ht & Liu, Z.; Yu, L. (2020) \\
\hline
\end{tabular}

\section{Appendix C}

Table A3. Descriptive Statistics.

\begin{tabular}{cccccc}
\hline Variable & Obs & Mean & Std. Dev. & Min & Max \\
\hline labor & 533 & 1.426 & 0.659 & 0.4 & 4.8 \\
aqi & 590 & 52.068 & 21.633 & 17 & 158 \\
age & 577 & 2.445 & 1.137 & 1 & 5 \\
wp & 566 & 1.09 & 0.287 & 1 & 2 \\
edu & 578 & 3.696 & 0.889 & 1 & 5 \\
income & 571 & 3.13 & 1.053 & 1 & 6 \\
pop & 564 & 3.768 & 1.192 & 1 & 3 \\
know & 589 & 1.591 & 0.637 & 1 & 1 \\
fluegas & 588 & 0.274 & 0.446 & 0 & 5 \\
urg & 590 & 3.251 & 0.688 & 1 & 3 \\
necessity & 590 & 1.41 & 0.712 & 1 & 6 \\
occ & 570 & 3.284 & 1.065 & 1 & 4 \\
ht & 577 & 1.818 & 1.212 & 1 & 30 \\
time & 559 & 2.732 & 2.204 & 0 & \\
\hline
\end{tabular}

\section{Appendix D}

Considering the significance of the control variable (wp), this study conducted group regression for indoor and outdoor samples in Table A4. Models 1-3 are the results of indoor samples, and the others are outdoor. Although we found in the previous study that the coefficient of the control variable $(w p)$ is significant, we should be very careful when explaining it. The main reason is that there were too few people who worked outdoors who answered the questionnaire. This is one of the shortcomings of this study, but also affects the generalization of the conclusions of this study. 
Table A4. Grouping regression of indoor and outdoor samples.

\begin{tabular}{|c|c|c|c|c|c|c|}
\hline & (1) & (2) & (3) & (4) & (5) & (6) \\
\hline & \multicolumn{3}{|c|}{ Indoor } & \multicolumn{3}{|c|}{ Outdoor } \\
\hline Variable & OLS & Oprobit & Ologit & OLS & Oprobit & Ologit \\
\hline aqi & $\begin{array}{c}0.0102 * * * \\
(0.0029)\end{array}$ & $\begin{array}{c}0.0221^{* * *} \\
(0.0054)\end{array}$ & $\begin{array}{c}0.0407^{* * *} \\
(0.0094)\end{array}$ & $\begin{array}{c}0.0056 \\
(0.0051)\end{array}$ & $\begin{array}{l}0.0210 * \\
(0.0115)\end{array}$ & $\begin{array}{r}0.0413 \\
(0.0264)\end{array}$ \\
\hline age & $\begin{array}{c}0.0058 \\
(0.0259)\end{array}$ & $\begin{array}{l}-0.0122 \\
(0.0443)\end{array}$ & $\begin{array}{l}-0.0485 \\
(0.0826)\end{array}$ & $\begin{array}{l}-0.0417 \\
(0.0750)\end{array}$ & $\begin{array}{l}-0.1206 \\
(0.1618)\end{array}$ & $\begin{array}{l}-0.1867 \\
(0.3686)\end{array}$ \\
\hline edu & $\begin{array}{l}-0.0045 \\
(0.0431)\end{array}$ & $\begin{array}{c}0.0101 \\
(0.0706)\end{array}$ & $\begin{array}{l}-0.0107 \\
(0.1372)\end{array}$ & $\begin{array}{c}0.0331 \\
(0.0946)\end{array}$ & $\begin{array}{c}0.1153 \\
(0.2070)\end{array}$ & $\begin{array}{r}0.3339 \\
(0.4785)\end{array}$ \\
\hline income & $\begin{array}{c}0.0261 \\
(0.0293)\end{array}$ & $\begin{array}{c}0.0483 \\
(0.0520)\end{array}$ & $\begin{array}{c}0.1339 \\
(0.0958)\end{array}$ & $\begin{array}{l}-0.0430 \\
(0.0968)\end{array}$ & $\begin{array}{l}-0.0742 \\
(0.2073)\end{array}$ & $\begin{array}{l}-0.1502 \\
(0.4269)\end{array}$ \\
\hline pop & $\begin{array}{c}-0.1496^{* * *} \\
(0.0291)\end{array}$ & $\begin{array}{c}-0.2149^{* * *} \\
(0.0457)\end{array}$ & $\begin{array}{c}-0.4082^{* * *} \\
(0.0865)\end{array}$ & $\begin{array}{l}-0.0543 \\
(0.0639)\end{array}$ & $\begin{array}{l}-0.0966 \\
(0.1281)\end{array}$ & $\begin{array}{l}-0.1387 \\
(0.3398)\end{array}$ \\
\hline know & $\begin{array}{l}0.0849 * \\
(0.0464)\end{array}$ & $\begin{array}{l}0.1429^{*} \\
(0.0821)\end{array}$ & $\begin{array}{c}0.2340 \\
(0.1491)\end{array}$ & $\begin{array}{c}0.2150 \\
(0.1612)\end{array}$ & $\begin{array}{c}0.4426 \\
(0.3325)\end{array}$ & $\begin{array}{c}0.7216 \\
(0.8903)\end{array}$ \\
\hline fluegas & $\begin{array}{c}0.0139 \\
(0.0644)\end{array}$ & $\begin{array}{c}0.0538 \\
(0.1066)\end{array}$ & $\begin{array}{c}0.0359 \\
(0.1878)\end{array}$ & $\begin{array}{c}0.2048 \\
(0.1626)\end{array}$ & $\begin{array}{l}0.6674^{* *} \\
(0.3226)\end{array}$ & $\begin{array}{c}0.9701 \\
(0.7019)\end{array}$ \\
\hline urg & $\begin{array}{l}-0.0036 \\
(0.0444)\end{array}$ & $\begin{array}{l}-0.0335 \\
(0.0761)\end{array}$ & $\begin{array}{l}-0.0254 \\
(0.1498)\end{array}$ & $\begin{array}{l}-0.0900 \\
(0.0948)\end{array}$ & $\begin{array}{l}-0.2856 \\
(0.1898)\end{array}$ & $\begin{array}{l}-0.4251 \\
(0.4281)\end{array}$ \\
\hline necessity & $\begin{array}{c}0.0402 \\
(0.0419)\end{array}$ & $\begin{array}{c}0.0585 \\
(0.0776)\end{array}$ & $\begin{array}{c}0.1594 \\
(0.1424)\end{array}$ & $\begin{array}{l}-0.0033 \\
(0.1167)\end{array}$ & $\begin{array}{c}0.0783 \\
(0.2398)\end{array}$ & $\begin{array}{c}0.3470 \\
(0.5713)\end{array}$ \\
\hline occ & $\begin{array}{c}-0.1323^{* * *} \\
(0.0323)\end{array}$ & $\begin{array}{c}-0.2329 * * * \\
(0.0568)\end{array}$ & $\begin{array}{c}-0.4011^{* * *} \\
(0.1059)\end{array}$ & $\begin{array}{c}0.0801 \\
(0.1154)\end{array}$ & $\begin{array}{c}0.1855 \\
(0.2368)\end{array}$ & $\begin{array}{c}0.2646 \\
(0.6533)\end{array}$ \\
\hline ht & $\begin{array}{c}0.0679^{* * *} \\
(0.0241)\end{array}$ & $\begin{array}{c}0.1242^{* * *} \\
(0.0417)\end{array}$ & $\begin{array}{c}0.2395^{* * * *} \\
(0.0763)\end{array}$ & $\begin{array}{c}0.1001 \\
(0.0930)\end{array}$ & $\begin{array}{c}0.2704 \\
(0.2081)\end{array}$ & $\begin{array}{c}0.4888 \\
(0.5353)\end{array}$ \\
\hline time & $\begin{array}{l}-0.0161 \\
(0.0116)\end{array}$ & $\begin{array}{l}-0.0242 \\
(0.0210)\end{array}$ & $\begin{array}{l}-0.0425 \\
(0.0379)\end{array}$ & $\begin{array}{c}0.0491 \\
(0.0851)\end{array}$ & $\begin{array}{c}0.0959 \\
(0.1773)\end{array}$ & $\begin{array}{c}0.1119 \\
(0.4575)\end{array}$ \\
\hline Constant & $\begin{array}{c}2.1105^{* * *} \\
(0.3055)\end{array}$ & & & $\begin{array}{c}1.2790 \\
(0.8686)\end{array}$ & & \\
\hline $\begin{array}{c}\text { Obs. } \\
\text { R-squared }\end{array}$ & $\begin{array}{c}444 \\
0.2262\end{array}$ & 444 & 444 & $\begin{array}{c}50 \\
0.3997\end{array}$ & 50 & 50 \\
\hline
\end{tabular}

Notes: Robust standard errors in parentheses. ${ }^{* * *} p<0.01,{ }^{* *} p<0.05,{ }^{*} p<0.1$.

\section{Appendix E}

Models (1) to (3) introduce different cross terms in Table A5, and the impact of air quality on labor supply is still significant. 
Table A5. Interaction effect.

\begin{tabular}{|c|c|c|c|}
\hline & (1) & (2) & (3) \\
\hline Var & Labor & Labor & Labor \\
\hline \multirow[t]{2}{*}{ aqi } & $0.0397^{* * *}$ & $0.0158^{* *}$ & $0.0102 * *$ \\
\hline & $(0.0085)$ & $(0.0065)$ & $(0.0051)$ \\
\hline \multirow[t]{2}{*}{ age } & -0.0539 & -0.0271 & -0.0339 \\
\hline & $(0.0778)$ & $(0.0750)$ & $(0.0760)$ \\
\hline \multirow[t]{2}{*}{ wp } & -0.5873 * & $-0.6079 *$ & $-0.6197^{*}$ \\
\hline & $(0.3282)$ & $(0.3313)$ & $(0.3348)$ \\
\hline \multirow[t]{2}{*}{ edu } & 0.1409 & $0.1947^{*}$ & 0.1951 * \\
\hline & $(0.1230)$ & $(0.1162)$ & $(0.1166)$ \\
\hline \multirow[t]{2}{*}{ income } & 0.1084 & 0.0693 & 0.0497 \\
\hline & $(0.0915)$ & $(0.0838)$ & $(0.0836)$ \\
\hline \multirow[t]{2}{*}{ pop } & $-0.3895^{* * *}$ & $-0.3921^{* * *}$ & $-0.4047^{* * *}$ \\
\hline & $(0.0820)$ & $(0.0770)$ & $(0.0780)$ \\
\hline \multirow[t]{2}{*}{ know } & $0.3440 * *$ & $0.3028 * *$ & $0.2695^{* *}$ \\
\hline & $(0.1413)$ & $(0.1256)$ & $(0.1279)$ \\
\hline \multirow{2}{*}{ fluegas } & 0.1272 & 0.1742 & 0.1628 \\
\hline & $(0.1777)$ & $(0.1781)$ & $(0.1773)$ \\
\hline \multirow[t]{2}{*}{ urg } & -0.1239 & 0.0357 & 0.0480 \\
\hline & $(0.1336)$ & $(0.1212)$ & $(0.1226)$ \\
\hline \multirow[t]{2}{*}{ necessity } & 0.1878 & 0.0886 & 0.1321 \\
\hline & $(0.1355)$ & $(0.1290)$ & $(0.1283)$ \\
\hline \multirow[t]{2}{*}{ occ } & $-0.2960^{* * *}$ & $-0.2620^{* * *}$ & $-0.2571^{* * *}$ \\
\hline & $(0.1013)$ & $(0.0954)$ & $(0.0948)$ \\
\hline \multirow[t]{2}{*}{ ht } & $0.2484^{* * *}$ & $0.6044^{* * *}$ & $0.2469^{* * *}$ \\
\hline & $(0.0728)$ & $(0.1575)$ & $(0.0672)$ \\
\hline \multirow[t]{2}{*}{ time } & -0.0409 & -0.0302 & $-0.2813^{* * *}$ \\
\hline & $(0.0392)$ & $(0.0364)$ & $(0.0915)$ \\
\hline aqi*sat & $\begin{array}{c}-0.0128^{* * *} \\
(0.0025)\end{array}$ & & \\
\hline aqi*ht & & $\begin{array}{c}-0.0068^{* * *} \\
(0.0026)\end{array}$ & \\
\hline \multirow[t]{2}{*}{ aqi*time } & & & $0.0043^{* * *}$ \\
\hline & & & $(0.0014)$ \\
\hline Observations & 494 & 494 & 494 \\
\hline
\end{tabular}

\section{References}

1. Zheng, Y.; Xue, T.; Zhang, Q.; Geng, G.; Tong, D.; Li, X.; He, K. Air quality improvements and health benefits from China's clean air action since 2013. Environ. Res. Lett. 2017, 12, 114020. [CrossRef]

2. Hanna, R.; Oliva, P. The effect of pollution on labor supply: Evidence from a natural experiment in Mexico City. J. Public Econ. 2015, 122, 68-79. [CrossRef]

3. Walker, W.R. Environmental regulation and labor reallocation: Evidence from the clean air act. Am. Econ. Rev. 2011, 101, 442-447. [CrossRef]

4. Adams, M.D.; Kanaroglou, P.S. Mapping real-time air pollution health risk for environmental management: Combining mobile and stationary air pollution monitoring with neural network models. J. Environ. Manag. 2016, 168, 133-141. [CrossRef] [PubMed]

5. Zhang, X.; Chen, X.; Zhang, X. The impact of exposure to air pollution on cognitive performance. Proc. Nat. Acad. Sci. USA 2018, 115, 9193-9197. [CrossRef] [PubMed]

6. Lichter, A.; Pestel, N.; Sommer, E. Productivity effects of air pollution: Evidence from professional soccer. Labour Econ. 2017, 48, 54-66. [CrossRef]

7. Li, X.; Qiao, Y.; Shi, L. Has China's war on pollution slowed the growth of its manufacturing and by how much? Evidence from the clean air action. China Econ. Rev. 2019, 53, 271-289. [CrossRef]

8. Liu, Z.; Yu, L. Stay or leave? The role of air pollution in urban migration choices. Ecol. Econ. 2020, 177, 106780. [CrossRef]

9. Zhao, Y.; Tan, Y.; Feng, S. Does reducing air pollution improve the progress of sustainable development in china? J. Clean. Prod. 2020, 272, 122759. [CrossRef]

10. Lin, S.; Xiao, L.; Wang, X. Does air pollution hinder technological innovation in china? A perspective of innovation value chain. J. Clean. Prod. 2021, 278, 123326. [CrossRef] 
11. Wang, F.; Wu, M. Does air pollution affect the accumulation of technological innovative human capital? Empirical evidence from china and India. J. Clean. Prod. 2021, 285, 124818. [CrossRef]

12. Chen, F.; Chen, Z. Air pollution and avoidance behavior: A perspective from the demand for medical insurance. J. Clean. Prod. 2020, 259, 120970. [CrossRef]

13. Liu, L.; Sun, R.; Gu, Y.; Ho, K.C. The Effect of China's Health Insurance on the Labor Supply of Middle-aged and Elderly Farmers Int. J. Environ. Res. Public Health 2020, 17, 6689.

14. Chen, F.; Chen, Z. Cost of economic growth: Air pollution and health expenditure. Sci. Total Environ. 2021, 755, 142543. [CrossRef] [PubMed]

15. Pu, S.; Shao, Z.; Yang, L.; Liu, R.; Bi, J.; Ma, Z. How much will the Chinese public pay for air pollution mitigation? A nationwide empirical study based on a willingness-to-pay scenario and air purifier costs. J. Clean. Prod. 2019, 218, 51-60. [CrossRef]

16. Tsurumi, T.; Managi, S. Health-related and non-health-related effects of pm2.5 on life satisfaction: Evidence from India, china and japan. Econ. Anal. Policy 2020, 67, 114-123. [CrossRef]

17. Park, J.; Loftness, V.; Aziz, A.; Wang, T.-H. Critical factors and thresholds for user satisfaction on air quality in office environments. Build. Environ. 2019, 164, 106310. [CrossRef]

18. García-Mainar, I.; Montuenga, V.M.; Navarro-Paniagua, M. Workplace environmental conditions and life satisfaction in Spain. Ecol. Econ. 2015, 119, 136-146. [CrossRef]

19. Ambrey, C.L.; Fleming, C.M.; Chan, A.Y.-C. Estimating the cost of air pollution in south east Queensland: An application of the life satisfaction non-market valuation approach. Ecol. Econ. 2014, 97, 172-181. [CrossRef]

20. Silveira, C.; Roebeling, P.; Lopes, M.; Ferreira, J.; Costa, S.; Teixeira, J.P.; Borrego, C.; Miranda, A.I. Assessment of health benefits related to air quality improvement strategies in urban areas: An impact pathway approach. J. Environ. Manag. 2016, 183, 694-702. [CrossRef]

21. Li, X.; Yang, Y.; Xu, X.; Xu, C.; Hong, J. Air pollution from polycyclic aromatic hydrocarbons generated by human activities and their health effects in china. J. Clean. Prod. 2016, 112, 1360-1367. [CrossRef]

22. Qiu, H.; Zhu, X.; Wang, L.; Pan, J.; Pu, X.; Zeng, X.; Zhang, L.; Peng, Z.; Zhou, L. Attributable risk of hospital admissions for overall and specific mental disorders due to particulate matter pollution: A time-series study in chengdu, China. Environ. Res. 2019, 170, 230-237. [CrossRef] [PubMed]

23. Hassan Bhat, T.; Jiawen, G.; Farzaneh, H. Air Pollution Health Risk Assessment (AP-HRA), Principles and Applications. Int. J. Environ. Res. Public Health 2021, 18, 1935. [CrossRef] [PubMed]

24. Luo, H.; Guan, Q.; Lin, J.; Wang, Q.; Yang, L.; Tan, Z.; Wang, N. Air pollution characteristics and human health risks in key cities of northwest china. J. Environ. Manag. 2020, 269, 110791. [CrossRef]

25. Yang, T.; Liu, W. Does air pollution affect public health and health inequality? Empirical evidence from china. J. Clean. Prod. 2018, 203, 43-52. [CrossRef]

26. Thomson, E.M.; Christidis, T.; Pinault, L.; Tjepkema, M.; Colman, I.; Crouse, D.L.; van Donkelaar, A.; Martin, R.V.; Hystad, P.; Robichaud, A.; et al. Self-rated stress, distress, mental health, and health as modifiers of the association between long-term exposure to ambient pollutants and mortality. Environ. Res. 2020, 191, 109973. [CrossRef] [PubMed]

27. Zhang, X.; Zhang, X.; Chen, X. Happiness in the air: How does a dirty sky affect mental health and subjective well-being? J. Environ. Econ. Manag. 2017, 85, 81-94. [CrossRef]

28. Liu, L.; Yan, Y.; Nazhalati, N.; Kuerban, A.; Li, J.; Huang, L. The effect of pm2.5 exposure and risk perception on the mental stress of Nanjing citizens in china. Chemosphere 2020, 254, 126797. [CrossRef]

29. Dzhambul, A.M.; Markevych, I.; Tilov, B.; Arabadzhiev, Z.; Stoyanov, D.; Gatseva, P.; Dimitrova, D.D. Pathways linking residential noise and air pollution to mental ill-health in young adults. Environ. Res. 2018, 166, 458-465. [CrossRef]

30. Klompmaker, J.O.; Hoek, G.; Bloemsma, L.D.; Wijga, A.H.; van den Brink, C.; Brunekreef, B.; Lebret, E.; Gehring, U.; Janssen, N.A.H. Associations of combined exposures to surrounding green, air pollution and traffic noise on mental health. Environ. Int. 2019, 129, 525-537. [CrossRef]

31. Feng, W.; Yuan, H. Haze pollution and economic fluctuations: An empirical analysis of Chinese cities. Clean Environ. Syst. 2021, 2, 100010. [CrossRef]

32. Sun, C.; Kahn, M.E.; Zheng, S. Self-protection investment exacerbates air pollution exposure inequality in urban China. Ecol. Econ. 2017, 131, 468-474. [CrossRef]

33. Freeman, R.; Liang, W.; Song, R.; Timmins, C. Willingness to pay for clean air in china. J. Environ. Econ. Manag. 2019, 94, 188-216. [CrossRef]

34. Shao, S.; Tian, Z.; Fan, M. Do the rich have stronger willingness to pay for environmental protection? New evidence from a survey in china. World Dev. 2018, 105, 83-94. [CrossRef]

35. Wang, Y.; Sun, M.; Yang, X.; Yuan, X. Public awareness and willingness to pay for tackling smog pollution in China: A case study. J. Clean. Prod. 2016, 112, 1627-1634. [CrossRef]

36. Chen, L.; Zhang, J.; You, Y. Air pollution, environmental perceptions, and citizen satisfaction: A mediation analysis. Environ. Res. 2020, 184, 109287. [CrossRef] [PubMed]

37. Zhang, Q.; Gao, T.; Liu, X.; Zheng, Y. Exploring the influencing factors of public environmental satisfaction based on socially aware computing. J. Clean. Prod. 2020, 266, 121774. [CrossRef] 
38. Ahumada, G.; Iturra, V. If the air was cleaner, would we be happier? An economic assessment of the effects of air pollution on individual subjective well-being in Chile. J. Clean. Prod. 2021, 289, 125152. [CrossRef]

39. Powdthavee, N.; Oswald, A.J. Is there a link between air pollution and impaired memory? Evidence on 34,000 English citizens. Ecol. Econ. 2020, 169, 106485. [CrossRef]

40. Ahmadiani, M.; Ferreira, S. Environmental amenities and quality of life across the United States. Ecol. Econ. 2019, 164, 106341. [CrossRef]

41. Yuan, L.; Shin, K.; Managi, S. Subjective well-being and environmental quality: The impact of air pollution and green coverage in china. Ecol. Econ. 2018, 153, 124-138. [CrossRef]

42. Laffan, K. Every breath you take, every move you make: Visits to the outdoors and physical activity help to explain the relationship between air pollution and subjective wellbeing. Ecol. Econ. 2018, 147, 96-113. [CrossRef]

43. Li, Z.; Folmer, H.; Xue, J. To what extent does air pollution affect happiness? The case of the Jinchuan mining area, china. Ecol. Econ. 2014, 99, 88-99. [CrossRef]

44. Yang, J.; Zhao, Y.; Cao, J.; Nielsen, C.P. Co-benefits of carbon and pollution control policies on air quality and health till 2030 in China. Environ. Int. 2021, 152, 106482. [CrossRef] [PubMed] 